\title{
Varieties of Market Competition in Public Employment Services. A Comparison of the Emergence and Evolution of the New System in Australia, the Netherlands and Belgium
}

\author{
Ludo Struyven \\ Faculty of Social Sciences \\ Research Institute for Work and Society \\ University of Leuven, Belgium \\ E-mail: ludo.struyven@kuleuven.be
}

Forthcoming in Social Policy and Administration, 48, 2: 149-168

This revised version: October 2013 


\section{Abstract}

This article deals with the evolution of a quasi-market system in the employment services in three countries: Australia, the Netherlands and Belgium. Based on an indepth analysis of the reform process over the past two decades, we arrive at the observation that Australia and the Netherlands, unlike Belgium, make comparable choices when restructuring this policy domain, although there context of a welfare state is different. Secondly, the new structures in those countries which have made the same choices are seen to evolve differently after only a short period of time. This article argues that no convergence towards the same competitive market model is to be found. It provides an institutional explanation by tracing elements of a new system logic which entered the existing structure and identifying change mechanisms which generate a cumulative process of smaller changes.

\section{Keywords}

quasi-markets, activation, employment services, institutional evolution, policy change, performance management

\section{Introduction}

The emergence of active labour market policies in the 1980s, to different extents, went hand in hand with a shift from the public employment service (PES) to private providers. Inherent to this new system of market competition are new steering models and instruments. The often suggested thesis is one of policy convergence between countries' quasi-market systems. The new market arrangements necessarily evolve from an open to a closed market and make way for new control instruments (Considine 2005b; Struyven 2007; Bredgaard and Larsen 2008; Weishaupt 2010; Van Berkel et al. 2011). 
These reverse shifts are considered as a rational consequence of inefficient, unsuccessful and costly contracting-out mechanisms. In this article, we build on an alternative explanation that countries do not necessarily converge towards the same model. Our explanation builds further on Streeck and Thelen's work on the notion of institutional evolution and change (Streeck and Thelen 2005; Mahoney and Thelen 2010). Unlike path dependence theory, small changes can equally well set in motion a process of gradual transformation. But in itself the process does not constitute the causal mechanism. In this article, we explain change due to an interaction of institutional, functional and actor-centric factors.

What is happening with PESs fits into the movement towards labour participation and privatisation (Gilbert 2002). Moreover, this is also related to reforms in the benefits system. The relationship between the two functions - benefits and job brokerage - is a fundamental and continually recurring area of tension in labour market policy. The activation goal again brings a certain rapprochement between the two. Introducing quasi-markets has formed part of the core of institutional reforms in the PES in several OECD countries since the early 1990s. Considine calls this a change in the administration paradigm with respect to labour activation, to which he assigns the term enterprising states (Considine 2001). This far-reaching institutional change entails a new institutional logic.

This research is concerned with the way in which three countries have implemented quasi-market arrangements in their PES system during the 1990s and the first decade of 2000s (until the financial crisis of 2008). Based on an in-depth analysis of the reform process, we arrive at the observation that Australia and the Netherlands, unlike Belgium, make comparable choices when restructuring this policy domain, although there context of a welfare state is different. Secondly, the new structures in those countries which have made the same choices are seen to evolve differently after only a short period of 
time. What brought the two reform countries Australia and the Netherlands to make a similar choice for the restructuring of their PESs ? How is it that Australia evolved after just a few years from an open to a closed market, whereas this did not happen in the Netherlands ? Why Belgium (Flanders) did not opt in the period studied for a new administrative structure with more scope for market competition, despite a far-reaching reform plan?

This qualitative comparative study is based on a comparison between three countries. The number of cases that are relevant for studying the phenomenon of market competition in PESs is by definition limited. Looking for the 'genuinely important cases' (Mahoney \& Goertz 2006), Australia and the Netherlands can be regarded as the extreme values (Ragin 1987) that are the most relevant for a study of market competition. Belgium is a representative of the public system. For this study a mix of research methods was used: interviews, documents, statistical data and secondary sources (Struyven 2006).

The following sections present the findings on the origin and further development of the system. First the origin and evolution of the system in the two 'reform countries', Australia and the Netherlands, is discussed; this is followed by a discussion of the evolution in Flanders. In what follows, we will first explain our theoretical model.

\section{A model for explaining policy change}

According to the theory of path dependence, a system fosters its own continuity; change is only possible if the existing structure is impacted upon by an exogenous factor, which cannot be explained on the basis of the preceding event (Pierson 2000a; Mahoney 2000; Deeg 2005). The possible transition to a new path implies a crisis moment or 'critical juncture', which acts as the trigger for change. On the contrary, the theory of 
Thelen (Thelen, 1999, 2003, 2004; Streeck \& Thelen, 2005: 9) identifies 'incremental change with transformative results' as a variant alongside abrupt change. With this study, we add several elements to the theory of gradual change and institutional evolution. These relate to the question of which factors - or, more accurately, mechanisms - cause change. Recent theories on path dependence attribute the cause of non-change to feedback mechanisms (Pierson 2000a; 2000b; Mahoney 2000) and to the internal logic or sequentiality of the path (Mahoney 2000: 530-531). Identifying the intervening processes in a sequence of events can reveal the causal mechanism. In itself, however, this does not constitute a sufficient condition to explain the evolution along a given path. Thelen/Streeck attribute the reasons for change to the forms in which change occurs, such as institutional layering (a new function is overlaid on an existing institution) or conversion (an existing institution acquires a completely new function). But in itself, the process does not constitute the causal mechanism. For these authors, what ultimately explains change are the political actors. The evolution of the process can be seen as an arena, in which the actors continue to struggle and renegotiate to gain influence and power. Explaining changes on the basis of the political power factor alone is however too limited. In our view, change arises due to an interaction of institutional, functional and actor-centric factors.

First there is the 'logic of action' (Deeg 2005) of the system. A system of market competition ushers in a complex concatenation of elements: a level playing field, management by results, functioning of the pricing mechanism, maximisation of placements, definition of obligations which have to be met by jobseekers (Struyven 2005; 2007). Only when these conditions have been met does the system become operational. This new logic conflicts with the elements of the existing logic, which continue to be necessary even in a market arrangement: the position of the public player, process control, the role of quality and experience alongside price, quality 
control, the provision of training for jobseekers and the sustainability of placements. If both logics are present, they 'compete' with each other, so that one logic suppresses the other. The new system logic in itself does not constitute a sufficient condition for change to occur. The inherent system logic can thus be distinguished from mechanisms of change. Another institutional factor lies with the parallel processes in related policy domains (Thelen 1999; 2004). Interaction occurs between reforms in the benefits administration and reforms in the job brokerage system (Considine 2005a; 2005b). This can go in two directions: from the benefits system to the job brokerage system or vice versa. If no interaction occurs, this change mechanism is absent.

A further explanatory factor is the functionality of the existing system. Increasing institutional density (Pierson 2000a: 483) leads to unintended effects, which generate a need for new changes which, in turn, in order to keep the system coherent, generate yet more pressure for change. An important factor here is the impact of new control structures and instruments on the organisation and implementation in the field. In this way changes alternate with each other rapidly and the outcome of the original intentions varies. An essential element is the way in which the functioning is perceived. Perception of success or failure of the existing system is cultivated. If the (lack of) success of the new system is cultivated, the change mechanism is present.

The third category has to do with the actors. Following the line of Skocpol (1992), we distinguish the political/administrative actor from the field of service providers, including the interest groups. Two mechanisms for change can be distinguished here: the changed political-bureaucratic power situation and the anticipatory behaviour of actors.

To summarize, small changes in a process culminate in successive gradual changes if an interaction occurs between the inherent system logic on the one hand and parallel reform processes, the cultivated success/failure of the new system, the changed power 
coalitions and the anticipatory behaviour of actors. How these mechanisms exert their influence on the process is illustrated by the countries studied here.

\section{The origin of market competition in Australia and The Netherlands}

The first step in analysing the process in the three countries is what changes when. Formal criteria, such as new legislation, are not an adequate criterion for establishing dividing lines. The various stages in the process towards institutional innovation are related to the elements on which the new institutional logic is based (Deeg 2005). The analysis of the process of change in Australia and the Netherlands begins with the situation as at the end of the 1980s. The first stage continues up to the point of the full

introduction of market competition, namely 1997 in Australia and 1999 for the Netherlands. We trace the path for each country in turn, followed by an explanation. The path change is illustrated in figure 1 and 2. 


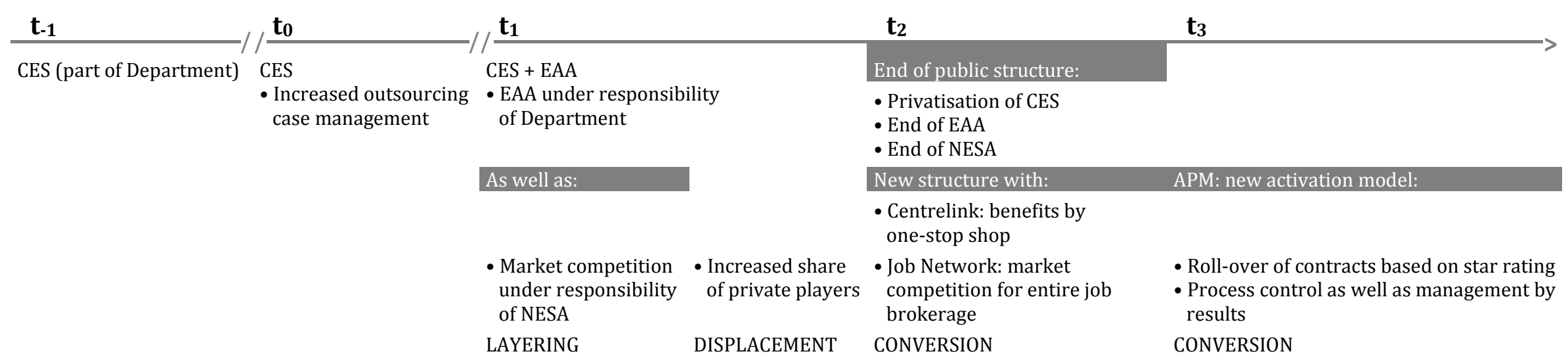

Figure 1 Forms of gradual change in the evolution of a market system in Australia

\begin{tabular}{|c|c|c|c|c|c|}
\hline$t_{-1}$ & $\mathbf{t}_{\mathbf{0}}$ & $\mathbf{t}_{1}$ & & $\mathbf{t}_{2}$ & $\mathbf{t}_{3}$ \\
\hline \multirow{6}{*}{$\begin{array}{l}\text { Arbeidsvoorziening } \\
\text { (part of Department) }\end{array}$} & Tripartite structure & Tripartite structure & & End of tripartite structure: & \\
\hline & & & & $\begin{array}{l}\text { - Privatisation of } \\
\text { Arbeidsvoorziening } \\
\text { - End of administrative } \\
\text { participation by social partners }\end{array}$ & \\
\hline & & As well as: & & New structure with: & \\
\hline & & - SWI: collaboration & & $\begin{array}{l}\text { - CWI: basic services by } \\
\text { one-stop shop }\end{array}$ & \\
\hline & & $\begin{array}{l}\text { - Purchasing by } \\
\text { benefit agencies } \\
\text { (UVIs + } \\
\text { municipalities) }\end{array}$ & $\begin{array}{l}\text { - Increased } \\
\text { purchasing }\end{array}$ & $\begin{array}{l}\text { - Private actors: reintegration by } \\
\text { compulsory open tendering }\end{array}$ & $\begin{array}{l}\text { - Abandonment of tender obligation for } \\
\text { municipalities } \\
\text { - Longer contract periods and contract } \\
\text { extension UWV } \\
\text { - Reintegration coaches UWV } \\
\text { - IRO: increased share individual } \\
\text { trajectories }\end{array}$ \\
\hline & & LAYERING & DISPLACEMENT & CONVERSION & LAYERING \\
\hline
\end{tabular}

Figure 2 Forms of gradual change in the evolution of a market system in the Netherlands 


\section{Australia}

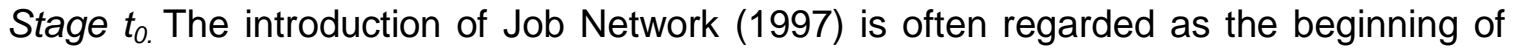
the reform of the system. In reality, however, the reform was introduced earlier, under the 'Working Nation ' initiative (1994); this was a first version of a competitive system, which in turn built on the system of 'case management' under the Newstart strategy introduced in 1989 for the long-term unemployed. And even before then there was a tradition of outsourcing job creation and training programmes, with the first initiatives introduced in the state of Victoria in the 1970s. The growing involvement of the private sector during this period took place with the CES as commissioning principal. The outsourcing laid the basis for the later private market.

The introduction of the new labour market strategy for the long-term unemployed was accompanied by changes to the conditions of eligibility for income support. The principle of 'reciprocal obligation', later 'mutual obligation', was explicitly embedded in the Australian benefits system for the first time under Newstart. All these elements formed the basis for the later Job Network.

From $t_{0}$ to $t_{1}$. The second step in a gradual change to a new path took place in 1994 when the Labor government published the White Paper Working Nation, a broad programme which incorporated case management for the reintegration of jobseekers and a job guarantee, called 'Job Compact ', for the long-term unemployed (18 months) and for all those who were at risk and of long-term unemployment (Commonwealth of Australia 1994b). Working Nation foresaw a gradual increase in the share taken by commercial and non-commercial players ${ }^{i}$. The statutory framework for the competitive system was given form in the 1994 Employment Services Act. The reforms in 1994 
followed a dual track: on the one hand a broadening of the playing field, on the other strengthening of the CES.

A characteristic of the new structure under Working Nation is that it was based on two logics:

1) a new market competition logic through the contracting of case management for the long-term unemployed to the private sector, headed not by the public player but by a new regulator, 'Employment Services Regulatory Authority' (ESRA);

2) continuation of the existing logic by placing the government case management player created by the CES, called 'Employment Assistance Australia' (EAA) within the ministerial department, outside the sphere of influence of ESRA.

Yet ESRA was not the only commissioning body; the government player EAA operated outside the authority of ESRA, was allocated a guaranteed market share and, as a spinoff from the CES, came under the Department, as did the CES itself.

With the introduction of the Job Compact, the government was generalising the principal of 'reciprocal obligation' (DEWRSB, 2000). The case manager was required to monitor its clients and inform the CES, including where the client failed to cooperate. This was linked to the start-up fee paid to the provider (Considine, 2005b).

From $t_{1}$ to $t_{2}$ A next step in the process towards a new path was the introduction of the Job Network system by the Conservative coalition government elected in 1996. A fully competitive market was introduced, while the EAA became an autonomous government agency without any guaranteed market share ${ }^{\mathrm{ii}}$. This decision led to a considerable saving over the coming three years (DEWRSB 2000). The new principle of 'mutual obligation' strengthened the obligations for jobseekers to do something in return for society. 
When Job Network was introduced, the activities of ESRA were suspended and the CES was wound up. The department took over the task of principal from ESRA. The other tasks of the CES were assumed by the department and Centrelink which served as a one-stop shop for a large number of services provided to the public.

Heavy emphasis was placed on outcomes. Accordingly, the share of outcome financing increased. Price competition was introduced for certain elements of the tender. The reform of 1997 forms the crystallisation of the figure that emerged under Working Nation, one not even rubber-stamped by new legislation in Australia (Considine 2005b).

The gradual transformation into a full market model explained. The partial change in the existing system brought elements of institutional renewal to the fore: the separation of principal and agent (at least for the ESRA portion); the use of financial incentives through the introduction of outcome fees; and the greater importance of placement. At the same time, the protected status of the CES and the guaranteed share allocated to the public player EAA were left intact. In other words, this phase of institutional change was a form of what Streeck and Thelen (2005) call layering: the existing system is left intact, but is layered with elements of a new system. At the same time, the elements of a new institutional logic forced the partially reformed structure in the direction of full market competition. The continued existence of the public system alongside the market system created an ambiguity in the existing structure which led to conflict due to the aversion of market players to the CES. In this transition from $t_{1}$ to $t_{2}$ the process took on two forms: displacement and conversion: displacement because the public logic gradually had to make way for the market logic; and conversion because the existing structure was converted in accordance with the new logic.

As stated in the theoretical section, we can identify four change mechanisms which help to explain the process of the nature of a full market model in the following way: 
Interaction with reforms in the benefits system. The great emphasis on compliance with obligations, first introduced in the Newstart programme, was continued under Working Nation. The creation of Centrelink under the coalition government in 1996 brought a solution for the intake and referral of job seekers, the selection of candidates in advance and the imposition of sanctions. Candidates who could not be referred to Job Network (because they did not possess the 'capacity to benefit'), had no choice ('mutual obligation') but to accept a work experience offer such as 'Work for the Dole'. This created an interaction between the process of tightening up the benefits regime and the process of market competition in job brokerage.

Cultivation of the failings of the existing system. In the 1990s there had been unrelenting negative criticism of the results of existing programmes and of the CES as a system, which was losing the support of employers and jobseekers. The failings of the existing structure were cultivated by an official evaluation by the department (DEWRSB 2000). Strengthening the grip of the department on the system. During the first reforms, the department retained control over the CES, while the beginning market came under the control of an independent regulator (ESRA). The CES ultimately also lost the support of the department. During the reforms of 1997 the CES was hived off, so that the department was able to assume the full role of principal and ESRA could be rendered redundant.

Anticipatory behaviour by actors. In 1994 the Labor government wanted to reform the CES structure in such a way that the reforms went far enough to be left intact if a government of a different colour should come to power. The reformers were in other words anticipating a subsequent reform. A growth scenario was projected for the beginning market, which was overtaken by developments in the market. Non-profit and profit actors, who saw their share of the playing field expanding, anticipated a further enlargement of the quasi-market. 


\section{The Netherlands}

Stage $t_{0 .}$ The Dutch PESs landscape was relatively calm until 1980, when preparations began for a new tripartite structure, introduced in the 1990 Manpower Services Act, which marked the end of the government monopoly on job brokerage. In the first half of the 1990s the practice of subcontracting for Arbeidsvoorziening increased as more scope was created for training programmes. In parallel with this, a quest was under way for a new institutional structure for the administration and implementation of the social insurance system. In the 1990s virtually all aspects of the social security system were subjected to major or minor reforms (Van der Veen \& Trommel 1999).

From $t_{0}$ to $t_{1}$. A first gradual change occurred in 1994, when certain tasks were configured according to a new logic. The new coalition, a combination of right and left, conducted a dual change:

1) on the one hand the basis was laid for the purchasing model, in which Arbeidsvoorziening began performing services on commission from the social insurance implementing bodies (UVIs) and local authorities;

2) on the other hand, a process was initiated of bottom-up cooperation between the public employment agencies, the municipal social services and the UVIs for intake and referral (the Cooperation Structure for Work and Income (SWI), which later gave birth to the Centres for Work and Income and the new Implementation Structure (SUWI). This double renewal was effected without altering the underlying structure of Arbeidsvoorziening. 
From $t_{1}$ to $t_{2}$. A third process took place in 1999, with the introduction of compulsory open tenders and the abandoning of Arbeidsvoorziening under the new SUWI structure. The new market logic was generalised and clarity gradually emerged in the position of the public service within the new market rather than alongside the market. There was an end to the co-administration by the social partners, who were given a purely advisory role, while the former Arbeidsvoorziening became a public provider in a position that was fully in line with the market.

The public employment agencies and benefits agencies that previously existed disappeared, to be replaced by two new national organisations:

1) for benefits, a single Implementing Body for Employee Insurance (UWV) was created instead of the five existing social insurance implementation bodies (UVIS) ${ }^{\mathrm{iii}}$ and the umbrella National Social Insurance Institute (LISV);

2) in the field of job brokerage, a number of tasks in the area of 'basic services' which were previously covered by Arbeidsvoorziening, the UVIs and the municipalities, became the responsibility of the Organisation for Work and Income, which managed a nationwide network of 131 Centres for Work and Income (CWI) in 110 municipalities (approximately one in five municipalities).

Both organisations were fully within the public domain. For the reintegration of jobseekers, subsistence benefit claimants and the disabled, the choice was made for a fully privatised market. The reintegration activities of the existing Arbeidsvoorziening were privatised in the form of a reintegration company, the state-owned company NV Kliq, bidding on an equal basis with other providers.

Since unemployment insurance benefits are limited in duration, many long-term unemployed people end up on subsistence benefit (usually 'Stream 4' clients). The municipalities are responsible for the implementation of social assistance benefits and 
also for subsidised work. The municipalities have a direct financial interest in outflow from subsistence benefitiv.

The gradual transformation into a full market model explained. As in Australia under Working Nation, the reforms in 1994 contained the ambiguity of a double system logic. The new logic was introduced while the logic of the public system remained intact - this is the process of layering. Gradually, the system of purchasing by benefits agencies (UWV and municipalities) came to dominate the existing structure - a process that can be characterised as displacement. In 1999 the structure was converted to bring it into line with new political objectives and - for the reintegration task - a new market logic; this process is characterised as functional conversion.

The four factors that influenced the process can be identified in the following way:

The embedding in the new implementation structure for social insurance. After the second tripartite Manpower Services Act came into force in 1996, it became clear that the future would be determined by the process of reform of the implementation structure for social insurance as a whole. An inherent element of the Coalition Agreement was that a balance needed to be found between the distribution of tasks in the public and private sectors. For which tasks ('reintegration') and in what form ('compulsory purchasing', 'compulsory tenders') market competition could form an alternative became clear only gradually.

The functioning of the public system. Right from the start of the introduction of the tripartite structure, Arbeidsvoorziening remained confronted with disappointing results. Despite the slight improvement in the results after the introduction of the new Act in 1996, political support for the public system evaporated entirely. The political masters reacted to the persistent financial impasse ${ }^{\mathrm{v}}$ with a combination of financial compensation mechanisms and political risk-aversion. 
The loss of political support to the tripartite structure. Many observers saw the tripartite experiment for Arbeidsvoorziening in the mid-1990s as doomed to failure. Neither the government nor the social partners regarded themselves as the owners of the organisation. Arbeidsvoorziening no longer belonged to anyone, according to one of the respondents. But it was not clear what could replace it.

The anticipatory behaviour of the actors involved. The various actors in the field began repositioning themselves strategically, and thus responding to anticipated developments. Both the UVIs and Arbeidsvoorziening anticipated developments and reinforced each other in their new roles. This created a coordination effect. Arbeidsvoorziening began projecting itself more as an attractive market player for the growing volume of activities via purchasing. The spending cuts also drove Arbeidsvoorziening in this direction. The UVIs, as principals, in turn anticipated the situation by purchasing services where they saw fit, even though this was not yet permitted. In order to position itself better in the growing 'market', Arbeidsvoorziening decided on its own initiative to split up the internal organisation into separate units within a single concern. At that time the management did not yet realise that the next step would be external splitting up. The decision for this external splitting came relatively late, and was speeded up after the definitive SUWI became known.

\section{The evolution of market competition in Australia and The Netherlands}

\section{Australia}

The basic mechanism of market competition which Australia has showcased to the world is the competitive tender procedure (OECD 2001; Productivity Commission 2002). However, for the third contract period 2003-2006, the Australian government partially 
removed the tender mechanism (roll-over). Whereas in the past the tender procedure occupied a central position, management by results via the star ratings now forms the heart of the system. Moreover, only fixed prices are now used and providers are paid after each completed interview with a jobseeker in accordance with a strictly regulated frequency. Direct intervention in the market share of the provider has replaced indirect management based on price competition and outcome financing. These interventions mean that the public-hierarchical logic has come to dominate. The break lies between the second and third contract periods, which according to respondents was a more radical transition than the transition in 1997 from Working Nation to the first edition of Job Network. This phase is marked by functional conversion in the process of Job Network. The transition between the two points in time (from $t_{2}$ to $t_{3}$ ) is represented schematically in figure 1.

The new activation model APM introduced a service continuum consisting of Job Search Support and Intensive Support, with in between periods of compulsory activity under the mutual obligation principle.

The star rating instrument clashed with the logic of market competition because the star ratings functioned purely as part of a public hierarchical logic and played no part in the transactions on the quasi-market in the individual choice from different providers. The dominant influence of the star ratings was reinforced by the linking of this mechanism to the contracts and the six-monthly review of the share of referred jobseekers. This made the quasi-market transparent, but it was a transparency that was unilaterally useful to the government.

Based on our analysis, the evolution can be attributed to the following four mechanisms: Interaction with the new model for the Australian welfare state. The permanent job search model of APM implies a close link between the department (DEWR) and 
Centrelink. But the increasing activation pressure exposed a cultural difference between the two organisations: the department was in favour of a firmer approach to jobseekers, while Centrelink favoured a milder approach. At Centrelink there was a tendency to broaden the service provided to jobseekers in order to increase its added value. In the view of the department, however, this went beyond Centrelink's role. The department wanted to prevent the former CES rising from the ashes.

The functioning of the new system. In the third contract period, the transition problems were worse than ever, the service became further standardised, problems such as 'parking' and limited freedom of choice were still apparent. The new IT-driven model imposed a heavy administrative burden on providers, as well as a heavier caseload and constant uncertainty regarding the intake volumes and income. To help the system run more smoothly, the government introduced a number of financial compensation measures. Together with the announcement of steadily improving results, these measures served to compensate for the institutional incongruence in the system.

The influential position of the department. Characteristic of the configuration of the quasi-market in Australia is the position of the central department in Canberra as the sole principal. The department can adopt an omnipotent stance and can unilaterally change the rules of the game. It can also mean that the prices are in reality too low. This undermines the trust between the parties involved. The new IT system further exacerbates the centralisation trend. The department is not willing to discuss changes and sticks rigidly to the stipulations of the tender and the contract.

The behaviour of market players. Throughout the successive rounds, there has been an increasing concentration of the market. The market concentration is strongly influenced by the automatic contract extension, the elimination of the pricing mechanism and the growing importance of past results. The providers only gradually realised what 
indications the new choices - flow continuum, IT system, enlargement of the target group - would have for the functioning of the systemvi.

\section{The Netherlands}

The further development in the Netherlands is marked by a period of increasing market competition between 2000 and 2003, followed by a period of new elements with resultant limited shifts in 2004-2008. This transition from $t_{2}$ to $t_{3}$ is represented schematically in figure 2. In the municipalities, the tender regime under SUWI and the outsourcing obligation lapsedvii. At the UWV there is the introduction of longer contracts, contract extensions and case management by reintegration coaches. Then there is the rapidly growing practice of devising individual trajectories in the context of the individual reintegration contracts (IRO). This phase can be identified as a form of layering. The effect is that market competition is strengthened because of the fairly unrestrictive conditions for companies and the open-ended budgeting for IROs.

The following four mechanisms can be identified.

Interaction with parallel processes. A first development was the creation of the individual reintegration contract (IRO), which was motivated by the political desire for a more client-centric focus of the SUWI structure. From their launch in 2004, the number of individual trajectories rapidly overtook the number of tendered trajectories. In this way freedom of choice was given a more central position in the system. A second development was the introduction of the Work and Social Assistance Act (WWB). At municipal level, a contradiction was perceived between the $100 \%$ responsibility for social assistance spending and the additional requirement imposed by central government to engage in tendering. The reasoning was that giving municipalities full financial responsibility would not require the imposition of any additional obligations. 
The functioning of market competition in the context of SUWI. In the period from 2002 there was growing criticism of the lack of figures on the results of the reintegration market. This explains the greater process control by the UWV, using performance indicators, satisfaction surveys, classification and profiling of jobseekers.

Building of a strong bureaucratic position. The existence of government organisations such as the UWV and CWI alongside the municipal services meant that power was more widely spread. As a result, the minister/ministry cannot simply push through plans unilaterally. Initially the UWV (and a number of municipalities) had the intention of cutting the preferential ties with the government-allied provider. This made the autonomously operating UWV a major proponent of a fully transparent tender procedure.

Anticipatory behaviour by actors. Finally, the evolution of the Dutch system has been influenced by the behaviour of key market players: the providers, united in the sector federation, and the social partners who (together with the municipalities) were assigned a consultative and advisory role. Both organisations anticipated the need for transparency and benchmarking of the market. It is an example of how the Dutch consensus-based 'polder model' still survives in the system of market competition.

\section{Explanation in comparative perspective: The Netherlands/Australia}

The Dutch evolution is much less pronounced than the Australian development towards more stable market relations, greater weight assigned to past results and greater process control. How can this be explained? The differing development in Australia and the Netherlands is related first and foremost to differences in institutional structure. Then there are differences in the form in which the tender mechanism is cast. Thirdly, there are also differences in the control instruments. 
First, the presence of several different principals created a very different starting point for the institutional structure in the Netherlands from that in Australia. It gave rise to a market with many principals (UWV, 480 municipalities, private employers ${ }^{\text {viii) }}$ and different, partially overlapping markets (for the disabled and jobseekers, social assistance benefit clients, sick employees). The pluralistic tendering system is attractive from the perspective of providers because it helps to spread the risk better and avoids dependence on a single principal. In Australia there is only one principal for the entire continent, which is moreover strongly centralised in Canberra. In Australia, the launch of a new tender round has a greater impact, because of its size (a single mastodon for all contracts) and duration (every three years). In the Netherlands, changes can be implemented more continuously and in the short term through the many national and municipal tenders, both successive and simultaneous. As a result, the evolution in the Netherlands is less abrupt than in Australia. Thirdly, the instruments used to control the market refer to the forms of intervention which direct and streamline the day-to-day

processes between principal, provider and jobseeker. They help establish the logic of action' of the system. As in the Australian quasi-market, quality control, performance measurement and benchmarking are becoming increasingly important in the Dutch quasi-market owing to the growing focus on quality and placement. Since these instruments have been developed and are currently administered by the providers' sector, they also function more as elements of a market logic then if they were in the hands of the government.

\section{Explanation in comparative perspective: The Netherlands/Belgium}

Like Australia and the Netherlands, at the end of the 1990s a new coalition government in the Flemish region launched a large-scale reform of the PES system. This plan was 
based on a new steering role with regard to the labour market. The aim was to split the existing PES structure into separate institutions for the control, c.q. purchasing tasks and implementing tasks. The plan exercised minds for four years, before ultimately being reaffirmed by decree as the existing Flemish PES, including its name ${ }^{\mathrm{ix}}$. The question arises why Flanders did not opt in the period studied for a new administrative structure with more scope for market competition ${ }^{x}$. This question is answered by exploring the different institutional configurations in Flanders and the Netherlands.

First, at the end of the 1990s, there were striking differences in the form of control: job brokerage in Flanders started from a rich tradition of joint management by social partners, and the Flemish public service became acquainted relatively early on with management by results via performance contracts, which guaranteed a contractually laid down budgetary framework (Struyven \& Verhoest 2005). The position of the local administration in Belgium is moreover limited due to the unlimited duration of unemployment benefits and, as a consequence, the residual nature of the locally governed social assistance system. There was also another important explanatory factor behind the expansion drive of the Flemish PES: the desire to make the most of the Flemish competence and throw off the old national shackles. After the state reform of 1988, unemployment insurance schemes remained a federal responsibility of the National Employment Service (RVA), while the responsibility for job brokerage and reintegration of jobseekers became a responsibility of the VDAB. To some extent unintentionally, this also fuelled a monopolist attitude on the part of the VDAB towards other players in the market ${ }^{x i}$. Secondly, there was no general climate in Flanders in favour of market competition and privatisation in the sphere of social security and PESs. Temporary agency work was less widespread in Belgium ${ }^{\text {xii }}$. Another difference relates to the position of trade unions and employers' organisations in the social insurance system. Historically, corporatism was deeply rooted in both countries in the organisation of the 
social security system. The job brokerage domain in the Netherlands formed an exception to this. In Belgium there was no general discussion about the position of the social partners in the management of the social security system. In particular, the trade unions in Belgium have acquired much greater support and legitimacy, with the result that their veto power is also greater when it comes to political reforms ${ }^{x i i i}$. The strong position of the social partners in the policy and management of labour market institutions can be explained by the high organisational density of employers' organisations and the trade union density among both workers and the unemployed (Ebbinghaus \& Visser 2000) $)^{\text {iv }}$.

\section{Conclusion}

This study shows that countries, which developed new market arrangements in their PES systems, do not necessarily converge towards the same model. The three countries studied each follow their own path regarding the direction in which the system is evolving. This direction cannot be anticipated in advance by the dynamics concealed within the change process.

Important events for change were the effective entrance of private commercial organisations to the market of publicly funded services, the separate positioning of the role of principal relative to the players' market and the autonomy or privatisation of the former public service. Defined in this way, the turning point for Australia came not in 1997 but in 1994. In the Netherlands, the turning point lies not in 1999, but in 1995, when the purchasing scheme for reintegration by municipal social services and benefits agencies was introduced. In turn, this was able to happen because of the process of 
smaller changes which preceded it. These earlier points in time characterise the gradual nature of the processes of change.

In each country, change arises due to an interaction of institutional, functional and actorcentric factors. An initial change mechanism is interaction with parallel processes. In both Australia and the Netherlands the field of job brokerage via the activation policy is once again more closely tied to the area of benefits. Through links to reforms in the broader social security system, a strong influence is exerted on the institutional route for job brokerage. In the period of the further development of market competition, the interaction with parallel processes explains the differences in the process. In Australia, another link is made to a reform of benefits (Active Participation Model), but not in the Netherlands. In Flanders, the intended reform at the end of the nineties did not mesh with a reform in the area of benefits. The absence of interaction with parallel processes is facilitated by the constitutional allocation of areas of competence between the federal state (competent for benefits) and the regions (competent for job brokerage). Secondly, in Australia and in the Netherlands, the faulty operation of the existing public structure facilitated the steps of reform in the mid to late 1990s. The negative perception placed high effectiveness pressure on the new system. In the Flemish political and bureaucratic context, no room was left for a sceptical attitude towards the public structure. The recently acquired constitutional autonomy in employment placement absolutely had to succeed.

The following two mechanisms relate to the coalition and the behaviour of actors. A change of course took place in the 1990s in Australia and the Netherlands with the help of political and bureaucratic power among the advocates of the reform. A coalition of public agency and government department was initially able to keep the public service outside the market. At the same time, actors and players on the market seemed to anticipate the arrival of a fully competitive market system. In Flanders, no broad reform- 
oriented coalition could be formed for the reform plan of 1999 because influential actors in the existing public structure for job brokerage were against reform and were supported in their views by the trade unions. From the further evolution of market competition in Australia in 2003, it appears that the government department responsible for the tender has such bureaucratic power that a change of course could be pushed through against the wishes of actors in the field. In the Netherlands, power is distributed more widely among different actors and, initially, subordinate actors could strengthen their position through anticipatory behaviour.

Here, we have given a primarily institutional explanation. Yet the question can also be asked as to the decisive role of political parties. In both Australia and the Netherlands the path for market competition was smoothed by progressive coalitions led by socialdemocratic politicians. In Australia it was a Labor government which introduced an early form of market competition in 1994, in the Netherlands it was the two successive 'purple' coalitions of 'red' social democrats and 'blue' liberals in the period 1994-2002 who stood at the helm of the reforms. In Flanders, too, it was a social-democratic minister who in 1994 introduced management by results for the Flemish PES and launched the reform plan of the PES in 1999, albeit without success. But in Australia the second, more radical phase was introduced under the subsequent conservative administration involving a coalition of liberals and nationalists. The conservative governments that followed the 'purple' coalitions in the Netherlands continued the trend of market competition and privatisation of the former public service. Further removed from the cases studied here, in Denmark, market competition was introduced in early 2003 under a conservative government (cf. Bredgaard and Larsen 2008). The choice for the introduction of market competition can thus not be traced back to the position of socialdemocratic parties in the government. 
Market arrangements also entail a new logic of performance management. The Australian case shows how this can inhibit the process of market competition. The new set of instruments penetrates all phases in the implementation of the service: it plays a leading role in the selection of providers, in the matching of clients to a certain service, in the measurement of performance, in the financing of the outcome, in the registration and in the quality control. New instruments generate solutions for specific problems, but also give rise to new problems which in turn generate new solutions. The result is a multiplication of unintended effects and interaction effects. With a greater focus on shortterm placements, authorities have less direct control of the quality of the process. There is a risk that the service will be reduced (for example by providing less training) or that the difficult groups will be excluded from intensive assistance because they are less profitable for the provider (the phenomenon of 'parking') (Considine 2005a; Struyven and Steurs 2005). Purchasing authorities have to rely on self-regulation by the market or have to fall back on more process control. For the jobseeker, freedom of choice continues to receive scant attention, while the pressure for activation is increasing. Market competition makes high demands on government steering capacities and on the responsibility and self-motivation of jobseekers. This is the greatest challenge compared with the public system.

\section{Acknowledgements}

This research has received funding from the European Community's Seventh Framework Programme under grant agreement No. 320121 (Project INSPIRES). It is mainly based on my own PhD work, for which I would like to thank my then supervisors Romke van der Veen, Erasmus University Rotterdam, and Jan Bundervoet, as well as David Thompson, Mark Considine, Jos Mevissen and Els Sol. I would also like to thank my informants, the reviewers and editors for valuable comments on the article.

\section{Notes}




\section{References}

Bredgaard T. \& Larsen F. (2008), Quasi-markets in employment policy: Do they deliver on promises? Social Policy and Society, 7, 3: 341-352.

CIETT (2000), Orchestrating the evolution of Private Employment Agencies towards a stronger society, Brussels: CIETT.

Commonwealth of Australia (1994a), Working Nation: Policies and Programs, Government White Paper. Canberra: Australian Government Publishing Service.

Commonwealth of Australia (1994b), Working Nation. The White Paper on Employment and Growth, Canberra: Australian Government Publishing Service.

Considine M. (2001), Enterprising States. The Public Management of Welfare-to-Work, Cambridge: Cambridge University Press.

ConsidineFout! Bladwijzer niet gedefinieerd. M. (2005a), Steering, Efficiency and Partnership: The Australian Quasi-market for Public Employment Services. In T. Bredgaard \& F. Larsen (eds), Employment Policy from Different Angles, Copenhagen: DJØF-publishers

Considine M. (2005b), The reform that never ends: Quasi-Markets and Employment Services in Australia. In E. Sol and M. Westerveld (eds), Contractualism in Employment Services. A New Form of Welfare State Governance, The Hague: Kluwer Law International, pp. 41-72.

Deeg R. (2005), Change from Within: German and Italian Finance in the 1990s. In W. Streeck \& K. Thelen (eds), Beyond Continuity. Institutional Change in Advanced Political Economies, Oxford: Oxford University Press.

DEWRSB (2000), Labour Market Review of Australia, Background Paper for the OECD Review Team, Canberra: Department of Employment, Workplace Relations and Small Business.

Ebbinghaus B. \& Visser J. (2000), Trade Unions in Western Europe since 1945, London: Macmillan.

Gilbert N. (2002), Transformation of the Welfare State. The Silent Surrender of Public Responsibility, Oxford: Oxford University Press.

Mahoney J. (2000), Path Dependence in Historical Sociology, Theory and Society 29: 507-548. 
Mahoney J. \& Goertz G. (2006), A tale of two cultures: contrasting quantitative and qualitative research, Department of Political Science and Sociology, Evanston, IL: Northwestern University.

Mahoney J. \& Thelen K. (2010), A Theory of Gradual Institutional Change. In J. Mahoney and K. Thelen (eds), Explaining Institutional Change. Ambiguity, Agency and Power, Cambridge: Cambridge University Press, pp. 1-37.

OECD (2001), Innovations in labour market policies. The Australian way, Paris: OECD.

Pierson P. (2000a), The Limits of Design: Explaining Institutional Origins and Change, Governance, 13, 4: 475-499.

Pierson, P. (2000b), Increasing Returns, Path Dependency and the Study of Politics, American Political Science Review, 94, 2: 251-67.

Pierson P. (ed), (2001), The New Politics of the Welfare State, Oxford: Oxford University Press.

Productivity Commission (2002), Independent Review of the Job Network: Inquiry Report, Canberra: Commonwealth of Australia.

Ragin Ch. (1987), The Comparative Method. Moving Beyond Qualitative and Quantitative Strategies, Berkeley/Los Angeles: University of California Press.

Skocpol T. (1992), Protecting Soldiers and Mothers: The Political Origins of Social Policy in the United States, Cambridge: Belknap Press of Harvard University Press.

Streeck W. \& Thelen K. (2005), Beyond Continuity. Institutional Change in Advanced Political Economies, Oxford: Oxford University Press.

Struyven L. (2007), Between Efficiency and Equality: New Public-Private Arrangements in Employment Assistance for the Unemployment. In J. de Koning (ed.) (2007), The Evaluation of Active Labour Market Policies. Measures, Public Private Partnerships and Benchmarking. Cheltenham, UK: Edward Elgar Publishing, pp. 193-220.

Struyven L. (2006), Hervormingen tussen drang en dwang. Marktwerking bij arbeidsbemiddeling. Leuven: Acco.

Struyven L. (2005), The New Institutional Logic of Public Employment Services. In T. Bredgaard \& F. Larsen (eds), Employment Policy from Different Angles, Copenhagen: DJØF Publishing Copenhagen, pp. 175-191.

Struyven L. \& Steurs G. (2005), Design and redesign of a quasi-market for the reintegration of jobseekers: empirical evidence from Australia and the Netherlands, Journal of European social Policy, 15, 3: 211-229. 
Struyven L. \& Steurs G. (2003), Towards a Quasi-Market in Reintegration Services: First Assessment of the Dutch Experience, Australian Journal of Labour Economics, 6, 2: 331-355.

Struyven L. \& Verhoest K. (2005), The Problem of Agency at Organisational Level and Street Level: The Case of the Flemish Public Employment Service. In E. Sol \& M. Westerveld (eds.), Contractualism in Employment Services, The Hague: Kluwer Law International.

Thelen K. (1999), Historical Institutionalism in Comparative Politics, Annual Review of Political Science 2: 369-404.

Thelen K. (2003), How Institutions Evolve: Insights From Comparative Historical Analysis. In J. Mahoney \& D. Rueschemeyer (eds), Comparative Historical Analysis in the Social Sciences, Cambridge: Cambridge University Press.

Thelen K. (2004), How Institutions Evolve. The Political Economy of Skills in Germany, Britain, the United States, and Japan, Cambridge: Cambridge University Press.

Van Berkel, R., de Graaf, W. \& Sirovatka, T. (eds) (2011), The Governance of Active Welfare States in Europe, Basingstoke: Palgrave.

Van der Veen R. \& Trommel W. (1999), Managed Liberalization of the Dutch Welfare State: A Review and Analysis of the Dutch Social Security System, 1985-1998, Governance, 12, 3: 289-310.

Visser J. (2006), Union membership statistics in 24 countries, Monthly Labor Review, January 2006: 38-49.

Visser J. \& Hemerijck A. (1997), 'A Dutch Miracle': Job Growth, Welfare Reform and Corporatism in the Netherlands, Amsterdam: Amsterdam University Press.

Weishaupt J.T. (2010), A silent revolution? New management ideas and the reinvention of European public employment services, Socio-Economic Review, 8, 3: 461-486.

\footnotetext{
i The Government anticipated that around 10 per cent of cases eligible for case management will be contracted out in 1994-95: 'It is planned that this figure will increase to around 20 per cent in 1995-96 and to 30-40 per cent in subsequent years' (Commonwealth of Australia 1994a: 131). In 1996-1997, the share of case management taken by the private (profit and non-profit) sectors had increased to $50 \%$.

ii Employment National steadily lost market share, and the organisation was wound up on 1 July 2003.

iii The merger of UVIs is regarded as the biggest nationalisation operation since the Second World War. The largest implementing body is GAK. The others are Cadans, GUO, SfB and USZO.

iv In the past municipalities were able to claim $90 \%$ of the funds needed for subsistence benefit from the central government. Since 1 January 2001 this 90/10 distribution has been converted to a 75/25 distribution. From 2002 onwards the $25 \%$ budget is distributed partly on the basis of objective and partly on the basis of historical distribution measures. All the funds are brought together in a single Work and
} 
Income Fund (FWI) at the municipality level. The Work and Social Assistance Act (2004) made municipalities $100 \%$ financially responsible.

$\mathrm{v}$ In May 1999 irregularities came to light and fraud was suspected involving ESF monies in the public employment agencies. It turned out that Arbeidsvoorziening did not have a separate project administration and also did not maintain the mandatory separate bank account for its ESF income. The financial embarrassment of Arbeidsvoorziening was increased significantly by the ESF scandal.

$\mathrm{vi}$ It should be noted that recently, there has been more consultation with the sector than in the past on the implementation of the new model.

vii Early and ahead of the SUWI evaluation in 2006; the more limited European tender rules and experience and expertise functioned as a dam in a number of municipalities.

viii Due to the privatisation of the risks of illness and incapacity for work (van der Veen \& Trommel. 1999), employers provide additional purchasing power on the reintegration market.

ix VDAB or Vlaamse Dienst voor Arbeidsbemiddeling en Beroepsopleiding.

$\mathrm{x}$ Instead of adopting a quasi-market system, the VDAB experimented with small tenders of reintegration trajectories for the long-term unemployed.

$x i$ In Flanders, the government monopoly remained in force until 1999, after publication of the ILO Convention 181.

xii Figures for 1999 show a penetration rate of temporary employment in the Netherlands and Belgium of $4.0 \%$ and $1.9 \%$, respectively, of total employment (CIETT 2000).

xiii Following Visser and Hemerijck (1997), the failure of corporatism in the Netherlands broke the dam of institutional stability and the social security system was laid open for thorough restructuring.

xiv Between 1970 and 2003 the trade union density in Belgium increased, against the European trend, from $42.1 \%$ (1970) to $54.1 \%$ (1980) and from $53.9 \%$ (1990) to $55.4 \%$ (2002), whereas in the Netherlands the trade union density fell from $36.5 \%$ per cent (1970) to 34.8 per cent (1980) and from $24.3 \%$ (1990) to 22.3\% (2003). Together with three other small European economies (Finland, Sweden and Denmark), Belgium succeeded in maintaining the trade union density that had been built up in the 1970s. By way of comparison: the sharp fall in trade union density also occurred in Australia, from $50.2 \%$ (1976) to $22.9 \%$ (2003), a fall of 27.3 percentage points (Visser, 2006). The parallel dwindling impact of the trade unions in Australia and the Netherlands suggests that this may have played a role in the market-based reforms of the public job brokerage service. 